\title{
The Dynamics of Learning History in the Formation of Nationalism of Bitung City High School Students
}

\author{
Meike Imbar* \\ History Education Department \\ Faculty of Social Science \\ Universitas Negeri Manado \\ Tondano, Indonesia \\ meikeimbar@unima.ac.id
}

\author{
Aksilas Dasfordate \\ History Education Department \\ Faculty of Social Science \\ Universitas Negeri Manado \\ Tondano, Indonesia \\ aksilasdasfordate@unima.ac.id
}

\begin{abstract}
The main problem in this study is the waning spirit of nationalism among the younger generation. The purpose of this study is to describe the history of learning process carried out by teachers at the high school level to form student nationalism. In this study, the method used is a qualitative approach to data collection through; observation, interview and questionnaire. Data sources in this study were teachers and high school students in Bitung city. Analysis of the data in this study used Miles and Huberman's approach. The research found that: The history learning process carried out by teachers at the high school level in Bitung city has been carried out dynamically both in terms of preparation and implementation. Indications of efforts to shape student nationalism in the learning process History in high schools in Bitung city can be seen in the formulation of objectives in the lesson plan and the selection of learning strategies, and it appears in the evaluation questions carried out. This study recommends the development of a historical learning model based on national insights.
\end{abstract}

\section{Keywords - History Learning, Formation, Nationalism}

\section{INTRODUCTION}

Every nation in the world has a valuable nation's history of being passed on to its young generation to understand the twists and turns of the nation's life that unfolds within a period. From the understanding of the history of the nation, it is hoped that the personality of the young generation can be shaped into figures that reflect the values of national character or national character. Furthermore, the process of inheriting the nation's history becomes essential in the current era of globalization. The era of globalization, which is marked by socio-cultural changes as a result of the progress of the development of information and communication technology, is suspected of having a wide impact on the younger generation. No doubt the outlook on life and lifestyle of the younger generation also experience changes in line with the progress exposed in plain sight. The difference in perspective on life is feared to be able to erode the values of nationalism of the younger generation, especially high school students, in addressing various problems that surround the life of the nation and state [1].

The socio-cultural conditions of the Indonesian people after the reformation revealed an ironic phenomenon between the purity of the ideals of reform and the reality that was displayed in the eyes of all components of the nation.
The Indonesian nation which is described as a friendly, polite and honest nation, hard-working, tolerant and various other labels of goodness now needs to be criticized because the reality that occurs in the community shows differences like "day and night". Various acts of violence between citizens, including those committed by the younger generation, coloured the news of the mass media almost every day. This condition indicates increasingly fading social, moral and ethical cohesion in behaving as citizens; and this clearly shows the values of nationalism that are proud to have experienced degradation. Nationalism is a concept that dominates the 20th century and remains hotly discussed and fought for in the practice of national life in the world. Nationalism is everywhere, gripping millions of people on every continent today. This proves its ability to inspire and echo among "the people" in ways that were previously only covered by religion. So that more careful attention is needed to the role of symbolic elements in the language and ideology of nationalism, as well as moral, ritual and emotional aspects in national discourse and actions.

To prevent the increasingly widespread erosion of nationalism values, the world of education plays an important role, especially related to the knowledge of benefits that originate from the nation's history. Furthermore, learning National History as a value-oriented subject matter becomes urgent to be empowered in education for young people. Through learning National History students, especially at the high school level, are taught to learn from the history of their nation.

However, the reality of the process of learning history in high schools feels boring, tedious and unappealing to students. This problem lies not only in the ability/competence of history teachers but also in the dynamics and quality of the learning process and the assessment process that takes place in classrooms. Whereas according to reference [2], [3] history learning must be able to discriminate according to the level of intellectual difficulties and professional values as follows: (1) gaining knowledge of historical facts; (2) to gain an understanding and appreciation of events, or periods, or people in the past; (3) gained the ability to evaluate and criticize historical work; (4) learn historical research techniques; and (5) learn to write history. Departing from the stages of learning history, the history learning process should be carried out in accordance with the level of student maturity with the full 
dynamics associated with learning strategies, methods and techniques as well as evaluation while continuing to prioritize quality.

For this reason, in-depth research needs to be conducted on the history learning process. Its dynamics in the context of forming the character of high school students based on nationalism, especially in Bitung City as a multidimensional port city where students can quickly meet and interact with complex communities and in these interactions students can absorb various values of life that may not be in accordance with the character of the nation. The role and function of the teacher in learning National History is urgent to be considered in the context of forming the intended character.

Based on the background description above, the research problem is formulated as follows: (1). What is the reality of the history learning process carried out by teachers at the high school level? (2). Are there any indications of efforts to shape student nationalism in the process of learning History in high school? (3). Is there a dynamic learning process of History in the context of forming nationalism carried out by teachers at the high school level? (4). How do teachers try to design and implement dynamic history learning in the context of forming nationalism in high school students? (5). What is the assessment process conducted by the teacher in the context of forming nationalism in high school students?

\section{RESEARCH METHODS}

The research method used is descriptive as a problemsolving procedure that is investigated by describing the current state of the subject/object of research based on facts that appear or as they are. Data collected, compiled and analyzed and interpreted the meaning of the data. The data collection technique was carried out with documentary study techniques and participant observation techniques which meant that the researcher not only reviewed/analyzed the data covered through the syllabus, lesson plans prepared by the teacher but also made direct observations of the learning process carried out by the teacher in class. The study was conducted on teachers in high schools located in Bitung city. The population that is the object of research is high school students in Bitung city with the following population description: 12 high schools with a total of 4225 students. Given the limited cost and time, the sample size is set at 40 (forty) people; and this has met a decent sample size in the study of between 30-500 people. Data collection techniques were carried out using instruments, namely questionnaires, guided by the instrument lattice that had been formulated.

By the research methods and techniques used, the research data analysis uses percentage analysis techniques where the data obtained is added up, compared with the expected amount and obtained percentages. Percentage formula as follows: $\mathrm{p}=\mathrm{f} / \mathrm{n} \times 100 \%$ [4]

\section{RESUlTS AND DisCUSSION}

\section{Historical Learning Process}

To obtain the results and discuss the research that has been carried out, the Percentage Analysis technique is used to process the data collected through a questionnaire through tabulation, analysis and interpretation. In preparing this data, each item of frequency is calculated to get a percentage of each respondent's answer by dividing the rate of the answers by the number of respondents then multiplied by $100 \%$. The results showed that in the historical learning process, the inclusion of the attitude of nationalism in the learning objectives was very well understood by the teachers. Such teachers have realized that the study of history is not merely the delivery of facts of historical events, but also for the formation of an attitude of nationalism. Learning history for the younger generation is not seen as a mere transfer of knowledge, but behind it, there is a primary goal that must be achieved, namely the formation of the Indonesian human character which rests on the nation's history. The results of this tabulation also show that there are still a small number of respondents who seem doubtful about the above statement. This is likely due to students not knowing or not caring about this problem. It is also possible that during the learning process students see that the teacher has not been able to develop skills in designing historical education goals for the affective aspect/domain of attitude. If this analysis is acceptable, then these teachers should get priority in attending the training. Learning according to reference [5] is a two-way communication process, teaching is carried out by the teacher as an educator, while learning is carried out by students or students. The learning process is not a process that takes place by itself but a process that is specifically designed by the teacher with a specific purpose. Furthermore, the learning process itself is a series of activities that involve various components, and components in the learning process include teachers and students. The teacher, as a fundamental component in a learning process, occupies a strategic position in carrying out the pursuit process to achieve the goals effectively.

The distribution of answers to items emphasizes the importance of the attitude of nationalism in historical learning material showing the existence of variations of responses; however, the percentage that approves the above statement is significant in terms of numbers. The difference between answers indicates that there are still a small number of history subject teachers who do not / do not understand the purpose of history learning. These teachers may not, as stated above, have no background in historical education. Still, it can also be categorized as teachers who are less capable of linking the realm of attitude to historical material. Besides, these teachers lack an understanding of the purpose and objectives of learning history for the younger generation. This lack of understanding can be caused by a lack of knowledge about learning History; so the learning process is carried out mechanically without any effort to instill nationalism values to form attitudes. Nationalism is understood by many as a double-edged knife, on the one hand, it is a positive thing that should be owned by someone about his country. On the other hand, it is a negative thing that is hated by others who feel the terrible consequences behind a sense of excessive nationalism. This gives rise to various definitions of nationalism under the perspectives of the defining experts. Therefore, it is first necessary to understand the understanding of nationalism etymologically.

According to reference [6] etymologically nationalism consists of the words Natie and National from Latin, Natio which means a nation united by birth, from the word Nasci which means to be born, so that when linked objectively then the most commonly expressed is language, taste, religion and civilization, region, country and citizenship. These aspects are the main factors or elements of nationalism which are very objective and which actively shape nationalism towards the formation of a national state. In general the equality of the factors mentioned above then gradually there is an 
additional element that is the equal right for everyone to play a role in the group or society and the existence of equality of economic interests, this is what became known as modern nationalism, so that later nationalism has played a significant and positive role in sustaining the growth of unity and unity [7].

Relating to the delivery of the objectives of history learning by the teacher to students in class before giving subject matter; the respondents who were students mostly recommended that the history subjects had done the stages of learning activities well. Submission of learning objectives to students before the action begins contains the intention so that students know and understand the competencies that are expected to be developed related to the material to be provided. Also, the development of the affective domain will be more effective if students have first understood the purpose of studying a subject matter of History. The results also showed that students recognized the teacher's ability to organize learning material to achieve the goal of forming an attitude of nationalism. This recognition is based on the skill demonstrated by the teachers in the learning process in front of their students. The teachers convey learning objectives that contain affective domains for attitude formation, and this is reflected in the organization of subject matter presented to students. Organizing history learning materials to achieve the goal of forming an attitude of nationalism is a skill that must be continuously developed by teachers. The development of these skills can be obtained through training and mentoring by competent experts; so that teachers are increasingly skilled in organizing learning materials that are aligned with learning objectives. There is a development of History learning material that is done by the teacher to provide a deep understanding of nationalism. The development of content is essential, considering the historical material at the level of secondary education is mostly a repetition of the material in basic education. The development of historical material which is adjusted to the objectives to be achieved in this case the development of nationalism attitude is intended to make the material in accordance with the level of development of students and enrich historical knowledge; so students have a comprehensive knowledge and their understanding of nationalism is deeper.

Students mostly feel the benefits of studying History by increasingly understanding the importance of being nationalist. By exploring the benefits of studying History by the participants and understanding the importance of being nationalist, the formation of national character can proceed effectively. Understanding the importance of being nationalist through studying History will encourage students to prepare themselves as members of the community who will oversee the survival of the Unitary Republic of Indonesia. Being nationalist becomes an essential requirement in the era of globalization in the face of significant changes in the world record; so as early as possible students begin to prepare themselves to face global changes. Meanwhile, according to reference [7], that many national definitions have been offered by experts, from Renan to H. Kohn, Hayes or Hertz, most emphasizing one aspect, among others: political, social, economic, cultural, and psychological aspects. Based on the fact that the nation is a multidimensional and comprehensive complex phenomenon, even a product of historical development, Sartono Kartodirdjo proposed the definition of the nation's definition which refers to a community of unity of life that includes various different elements in ethnic aspects, class or social group, the flow of belief. Linguistic culture and all of which are integrated with historical developments as a united political system based on solidarity that is supported by a shared political will.

Ernest Renan, a great poet in France, made a well-known definition in a famous speech about the nation called "Qu 'est ce Qu'une nation?", What is a nation? He answered that the nation was a matter of feeling, a matter of mere will to live together (le desir de vivre en semble) which appeared in a large group of people whose fate was the same in the past, especially in shared sufferings. From this definition, Renan denies that national nation or nationalism arises because of equality or race (blood), or because of the balance of religion and language [8].

\section{Formation of Student Nationalism}

Based on the research questionnaire obtained data that the majority of respondents agreed that the teacher encourages students to read history books to form nationalism. This data becomes interesting; because to motivate students to read quality history books; consequently the teachers must have read the books or can also have the books or these books are stored in the school library; in other words, students can reach the books offered. The literacy ability of students is something that needs to be developed in Indonesia. The lack of literature, the high price of books and the culture of reading are not yet a challenge for history teachers. For this reason, the teacher's initiative by encouraging and offering quality history book titles is something that should be appreciated.

Furthermore, the results of calculating the frequency of answers about the history teacher is that someone who likes to read history books shows that most respondents agreed with the statement. Respondents who are students will know a history teacher is a person who likes to read history books through the teacher's appearance in presenting history lesson material. His mastery of historical knowledge; and its ability to convey material in a coherent and comprehensive manner gives the impression of being someone who has extensive experience for students. Also, students can observe through history books that are owned by the teacher and offered to students to read. Having fun reading history books will make learning history in classes not dry and tasteless.

The results showed that the majority of respondents agreed that the history teacher at his school was familiar with technology and had used the internet as a source of information knowledge. In the era of rapidly developing information technology; teachers must have the ability to use technology in the application of the learning process. Without the ability to access knowledge through technological sophistication such as the internet, the teacher will be left behind in terms of renewal of education. Besides the ability to access knowledge through the internet; teachers are also expected to be able to guide students to find the right web address in studying historical material as a comparison material, enrichment of the material that has been obtained at school. Through assignments to students; then students are encouraged to use the internet as a source of learning as well.

Furthermore, the results of the research teacher showed that the History teachers in Bitung city had an awareness that many historical learning resources were available and needed to be well utilized by students. Related to the formation of an attitude of nationalism; it turns out the teachers understand that their limitations are to provide a maximum understanding of the philosophy of nationalism. The sources 
of history learning outside the teacher itself are available variously around the students that need to be utilized by the students themselves. With the teacher recommending various learning resources also shows that the teacher has already known and used these multiple sources. This is important, so that teacher supervision of learning resources continues; especially electronic learning resources through the internet, for example.

For historical screening films in the classroom during the learning process takes place is not an easy thing. Schools must-have equipment for film screenings as well as the film itself; in addition, film screenings also require sufficient time duration. However, in today's technological era, film screenings can already be done quickly; each student can even do it with a personal device that is a laptop. Teachers and students can access the YouTube site and choose films that are relevant to the topic being taught. Film media can be used to overcome the saturation of learning, especially for historical material that is repetitive. The advantage of film media is the portrayal of the character of historical actors to life and the behaviour displayed can be a source of inspiration for students in managing their nationalism.

In learning history, teachers using LCD media show a constellation of almost "fifty-fifty" in the sense that more than $50 \%$ of respondents state their agreement; but the rest did not argue or disagree. In schools that have advanced in the mind that school facilities are well available, for example in every class LCD is installed with a good monitor screen; then learning with the LCD is possible. LCD will significantly assist teachers in presenting learning material; at the same time, it can also be used to play films, music relevant to learning material. By using LCD media, the teacher is required to prepare learning materials as attractive as possible; because the presentation of subject matter can be done by combining all media elements, such as text, video, animation, images, graphics and sound into one presentation unit. For that in schools that have media like this; History teachers need to consider using it because of the many advantages of this media.

The classes in schools in Bitung city, history teachers have implemented a dynamic history learning process by utilizing the diversity of available media. This can be interpreted that history teachers realize that as designers of the learning process teachers are required to be able to design learning by utilizing various types of media and learning resources that are appropriate for the learning process to take place effectively and efficiently. For this reason, the teacher must master and be skilled in operating various learning media that are available and suitable/appropriate to be used by the learning material.

Teachers who encourage students to watch certain historical films shown in theaters / television are teachers who monitor the development of the world of film and television. It is recognized that today the Indonesian film world is stretching forward and quite a lot of quality historical films are produced and marketed in cinemas. As for television, the emergence of historical documentaries or historical settings is a progress in order to shape historical awareness for viewers. Historical films can be a unique source of learning for students.

As it is known that the process of learning history through field trips to historical objects / sites around the student's environment can provide a unique experience for students. The experience is in the form of appreciation of local historical values obtained through observing, recording and asking questions about things that are in/around historical objects/sites. Local historical values are essential to be taught to students so that they understand their regional contribution and participation in the formation and development of this country; so as a young generation, they are encouraged to participate also in advancing their country and nation. The learning process through field trips to historical objects/sites around the school/residence will increase awareness of local history that is no less important than national history. The teacher also evaluates the respondent's attitude in attending the Flag Ceremony at school. This means that the assessment conducted by the History subject teachers in high schools in Bitung city does not only revolve around cognitive aspects; but also the affective dimensions. The assessment of attitudes following the Flag Ceremony shows that the teacher realizes that sacrifice for the nation must start from small things that seem trivial. Flag ceremonies if examined can be categorized as a ceremonial that can sometimes not be interpreted, but for education, the history of the flag ceremony can be classified as an appreciation of students for the struggle carried out by the heroes as well as an embodiment of a commitment to defend the country and nation. For this reason, the History subject teacher who conducts an assessment of students' attitudes in participating in the Flag Ceremony is a history teacher who is aware that the formation of nationalism can start from small things.

Furthermore, the subject teacher History in the assessment of learning outcomes is not only focused on the cognitive domain but also the affective domain which in this case is related to attitudes in dealing with fellow peers in class. The respondent, who is a student is an individual and also a social creature who needs other people in their interactions with the social environment. School/class is the first social environment outside the family which is a social laboratory for a student. Attitudes in dealing with peers in school/class become learning in relationships with a broader social scope. Therefore, subject teachers need to assess attitudes in relationships with peers in school/class so that deviant behaviour, lack of awareness in an association can be detected as early as possible so that students are prepared for broader relationships in society. With a good relationship, students are expected to later together with citizens be able to continue the culture of their people. The majority of history exam questions compiled by teachers are mostly only in the form of essays. Understanding the form of essay questions is a form of questions that are easily arranged by the teacher but requires time to examine them. In addition, the form of essay questions can provide a large and broad opportunity for students to express their knowledge freely in answering questions on the exam. The critical power of students is tested when dealing with questions in the form of essays / questions only. However, in the practice of learning there are still teachers who choose the preparation of questions in other forms such as objective questions. In the form of objective questions the teacher is indeed rather difficult to arrange the problem, but in the examination it becomes easy with a short time. Whatever the form of exam questions is not a problem, as long as the History teacher is able to balance out and be able to arrange questions correctly and validly to measure students' ability to learn History.

Calculation results for item no. 30 listed in the table above shows that respondents' answers varied, although most agreed with the statement above. The test questions in the form of essays by including questions about the attitude of 
students towards the life of the nation can be categorized as a matter of open essay tests in the sense that students are given the freedom to express their opinions. By asking questions about students' attitudes related to national life that is relevant to the material that has been presented will open up opportunities for students to make the life of the nation as an "inherent" part of themselves who are citizens. This is in line with the purpose of learning history so that students can make the history of the nation as a mirror to act on today and plan for the future. Students at the high school level must be asked questions related to their attitude to the life of the nation because later they will be the next generation.

Reference [9] said that in the learning process, the teacher does not only act as a model or role model for the students he teaches but also as a manager of learning. Like other subject teachers, History subject teachers in high school are also expected to be able to manage history learning into interesting lessons, stimulate interest, open up insights and moreover form personalities derived from historical values that have been learned. This is important for every History teacher to understand because even though history belongs to the social sciences family, history occupies a unique position. The uniqueness of history learning lies in the time factor that most distinguishes history from other social sciences.

For this reason, according to reference [10] the historical learning process that has so far been dominated by teachers conveying information and students memorizing information - needs to be changed by providing a variety of learning experiences developed so that students can also have experience in reconstructing historical events, learning experiences that allow students to develop thinking skills, historical procedural abilities, apply various analytical skills, draw lessons from history, and use them for their lives in the present. For this reason, according to him in the process of learning history, the teacher needs to determine the approaches, methods, teaching techniques in an effort so that students can learn to gather sources of information, criticize sources, draw information from sources, sequence information, apply the law of causation, analysis events, interpreting events, reconstructing historical events, drawing lessons from history, and utilizing the acquired abilities for the lives of today's students.

The above description shows that the history learning process is not an instant learning process or that is compiled instantly, but rather a learning process that is designed and implemented by empowering all the professional abilities of the teacher as well as the learning environment and available facilities. The results of research conducted by reference [11], concerning the Creativity of History Teachers in the Learning Process: Case Studies in Bandung Municipal High School, among others, show that history teachers in Bandung are still patterned rigid or less flexible in teaching, being less willing to take the initiative and risk in trying to implement new strategies, preferring things that are accustomed to or "safe" for themselves, rather than trying something "new", and less accustomed to learning and being challenged to "solve problems".

However, it was Renan's great theory that inspired Sukarno to fight the Dutch in fighting over West Irian, a desire to be united in wanting to unite with two different races namely Melanesia and Malay and against the Dutch by saying they were carriers of colonialism, world capitalism, this was more evident from the radio speech, from the leader chosen unanimously by the Indonesian Independence
Preparatory Committee (PPKI) as the first head of state, on August 23, 1945, saying: "My people are all in Sumatra, in Java, in Borneo, Sulawesi, the Lesser Sunda Islands, Maluku, from Atjeh to Merauke ". In this connection, Harsya W. Bachtiar said it was inconceivable that the Proclamation of Independence on August 17, 1945, turned out to ask the entire Dutch East Indies including West Irian (now Papua) to unite by using the slogan "from Sabang to Merauke". Also by ignoring the symbol of the Indonesian state, Sukarno said that Indonesia was nationally concerned with "Tunggal Ika", while the condition of our nation which was right "Bhineka" which in this case needed attention. Because it turns out that it ignores each ethnic group or "micro-nation" region. Soekarno's nationalism as the leader of Indonesian thinkers, often stressed that the understanding of the nation or nationality of Indonesia was based on the theory or thought and definition of Ernest Renan about the knowledge of the nation as a political concept.

Another definition of nationalism as in the country watch note: "nationalism is an important social and political phenomenon that involves the process of making a nation or a nation-state into a definable identity" [12]. From this definition, it can be understood that nationalism encompasses various aspects of society in the context of forming a national identity or the formation of a nation itself. In line with that according to Greenfield and Chirot as quoted by Karim stated that "nationalism is a set of ideas or sentiments that carry a conceptual framework of national identity that is often present along with various other identities such as occupation, religion, ethnicity, language, territorial, class, gender." This statement shows that the scope of nationalism is very broad-reaching in all aspects of human life in groups/institutions. Related to the above description Anthony D. Smith argues that nationalism today is interpreted as (1) a process of formation, or growth of nations; (2) a sentiment or awareness of having the nation concerned; (3) a language and symbolism of the nation; (4) a social and political movement for the nation concerned; (5) a doctrine and ideology of the nation, both general and specific" [13]. He further explained that "the use of the first meaning, the process of forming the nations is extensive. The process itself includes a series of processes that are more specific and often form objects of nationalism in a more narrow sense.

The explanation above confirms that the concept of nationalism is always associated with the nation-state so that the element that cannot be missed in discussing nationalism is the element of citizens. So, citizens have an obligation to build nationalism as a form of loyalty to the nation-state. Furthermore, teachers, as part of citizens, have the noble task of building nationalism for themselves and also for students.

\section{CONCLUSION}

History learning process carried out by teachers at the high school level in Bitung city has been carried out dynamically both in terms of preparation and implementation. Indications of efforts to shape student nationalism in the learning process History in high schools in Bitung city can be seen in the formulation of objectives in the lesson plan and the selection of learning strategies, and it appears in the evaluation questions carried out. There is a dynamic of the history learning process in the context of forming nationalism which is carried out by teachers at the high school level in Bitung city. The dynamics can be seen in the variation of learning strategies, differences in learning 
media and questions that are designed. The teacher's effort to design and implement dynamic history learning in the context of forming nationalism in high school students is made by studying the material and linking it with the nation's problems which are able to be responded to by students. The assessment process carried out by the teacher in the context of forming nationalism in high school students is carried out by assessing the attitudes and behaviour of daily students in school both in attending the flag ceremony and in association with peers at school/class.

\section{ACKNOWLEDGMENT}

The author would like to the Dean of Faculty of Social Science, Manado State University in supporting the publication of this article.

\section{REFERENCES}

[1] M. Imbar, A. Dasfordate, and Y. Burdam, 'History Learning based on Minahasa Local History', in Proceedings of the International Conference on Social Science 2019, 2019, vol. 383, pp. 612-619.

[2] B. Garvey and M. Krug, Models of history teaching in the secondary school. Oxford: Oxford University Press, 1997.

[3] H. Sjamsuddin, 'Model Pendekatan Pembelajaran Sejarah Dari Isus-Isu Kontroversial, Sejarah Komparatif Ke Analisis Tekstual', A g a s t y a, vol. 2, no. 1, pp. 11-20, 2012.
A. Suharsimi, Manajemen penelitian. Jakarta:
Rineka Cipta, 2009.

[5] S. Sagala, Konsep dan Makna Pembelajaran. Bandung: Alfabeta, 2005.

[6] H. Kohn, The age of nationalism: The first era of global history, vol. 1380. Harper, 1962.

[7] S. Kartodirdjo, 'Nasionalisme lampau dan kini', in Dinamika Nasionalisme Indonesia, D. I. Palit, Ed. Salatiga: Yayasan Bina Darma, 1999.

[8] E. Renan, Apakah Bangsa Itu? Jakarta: Alumni, 1994.

[9] W. Sanjaya, Pembelajaran dalam implementasi kurikulum berbasis kompetensi. Jakarta: Kencana, 2006.

[10] H. S. Hasan, 'Kurikulum Pendidikan Sejarah Berbasis Kompetensi', in Makalah pada Seminar Nasional Ikatan Himpunan Mahasiswa Sejarah SeIndonesia (Ikahimsi) XII. Semarang, 2007, vol. 16.

[11] D. Supardan, 'Pembelajaran Kesadaran Sejarah berbasis Pendekatan Multikultural dan Perspektif Sejarah Lokal, Nasional, Global dalam Integrasi Bangsa', Disertasi SPS UPI Bandung, 2004.

[12] J. . S. Djiwandono, 'Dimensi Internasional dan Integrasi Nasional: Tinjauan Teoretis', in Integrasi Nasional, Teori, Masalah dan Strategi, Safroedin Bahar, et al., Ed. Jakarta: Galia Indonesia, 1999.

[13] A. D. Smith, Nasionalisme Teori Ideologi Sejarah. Jakarta: Erlangga, 2003. 